\title{
Certifications in the Academic Process Oriented to the Reputational Capital of Brands of Brazilian HEIs
}

\author{
K. K. Cox, and R. De-Bortoli
}

\section{ABSTRACT}

\begin{abstract}
Considering the analysis of the academic process oriented to the reputational capital of the HEI brands, it arrive three main certifiable objects with impact on the reputation of universities: 'individual teaching advice' - applied to perform the main tasks of the process, the ' self-efficacy '- present in the evaluation of the work plan that guides the student's actions in the process and' disclosure '- which brings academia closer to society and generates a positive internal culture. The objective of this work is to identify how to carry out the certification of these objects. As a research methodology, three quasi-systematic reviews were applied, with successive refinements of articles collected on the CAPES Portal and the results were compiled. It was possible to identify that training followed or monitored by evaluations, and practical tests, also called challenges, are the forms of certification prevalent in this scope. The skills developed from the certifications considered were also listed, with the most mentioned being highlighted, such as the development of social skills, strengthening the commitment to the career and participation in the community of continuous learning; being observed that these favor the reputational capital of university brands.
\end{abstract}

Published Online: March 29, 2021

ISSN: $2736-4534$

DOI : 10.24018/ejedu.2021.2.2.69

\section{K. K. Cox*}

Federal University of Sergipe, São

Cristóvão, SE, Brazil.

(e-mail: kenia@dcomp.ufs.br)

R. De-Bortoli

Federal University of Sergipe, São

Cristóvão, SE, Brazil.

(e-mail: robelius@yahoo.com.br)

*Corresponding Author

Keywords: brands, certifications in the academic process, competitiveness, reputational capital

\section{INTRODUCTION}

The certification programs, according to [22], can be incorporated into the disciplines of Higher Education Institutions (HEIs) to promote content reinforcement, as well as introduce new solutions, tools and skills required by the industry; [15] state that, in recent years, in order to increase professional competence, many universities have stimulated the obtaining of certificates by students through tutoring; and for [5], certifications have been considered relevant for many countries in order to fill the lack of validation of the success of training initiatives; and guaranteeing synergy between professionalization and the demands of the economy, innovation, progress and consumer protection.

With a view to providing services and providing suitable products to users of HEIs, it is worth valuing intangible assets, such as their reputation and therefore their brands; which can be implemented through an academic training process oriented to the reputational capital of IES brands. In the context of the market where universities are today, [16] recommend that these institutions should present a distinction in their identities and understand how the attributes of their brands - meaning, image and reputation promote communication with the parties involved - teachers, students, employees, graduates and society in general, including employers.

Reputational capital is considered to be the harmony between what makes the distinction, has duration and is essential in the organization according to its managers identity; and how stakeholders perceive it - image. The closer the identity to an organization's image, the greater its reputational capital.

Business processes, whether public or private, promote harmony between methods, techniques, tools and objectives of the organization, in line with the expectations and needs of customers and society, according to [9]. In the academic environment, the effects of business processes have an impact on students, with the expanding their repertoire of scientific methodological foundation and their interaction with the community outside the HEI; about society, with the offer of qualified professionals and about the HEI itself, such as improving the use of intangible assets, such as the reputational capital of brands; since academic business processes are productive through researches, it can generate knowledge and innovations.

Reference [10] propose an academic process oriented to the reputational capital of the HEI brands. Brands, in a pragmatic way, correspond to a tool capable of creating a synergistic relationship with the user of a product or service and of differentiation in relation to its competitors; their management is not static, since it must constantly follow the expectations of those who use them.

The aforementioned process was presented using a SIPOC diagram (Supplier, Input, Process, Output and Customer), proposed by [2], and with the application of the UML 
(Unified Modeling Language) notation, in which two main tasks are identified: 'Definition and Evaluation of the Work Plan', composing the process or process, positioned in the middle of the Figure 1; suppliers or supply - which define specifications to be met by the process and references, positioned at the top of the aforementioned figure; inputs what is processed, on the left; final values or output - result of the process and customers or customers - those who receive the generated products, on the right; resources consumed in the process, bottom.

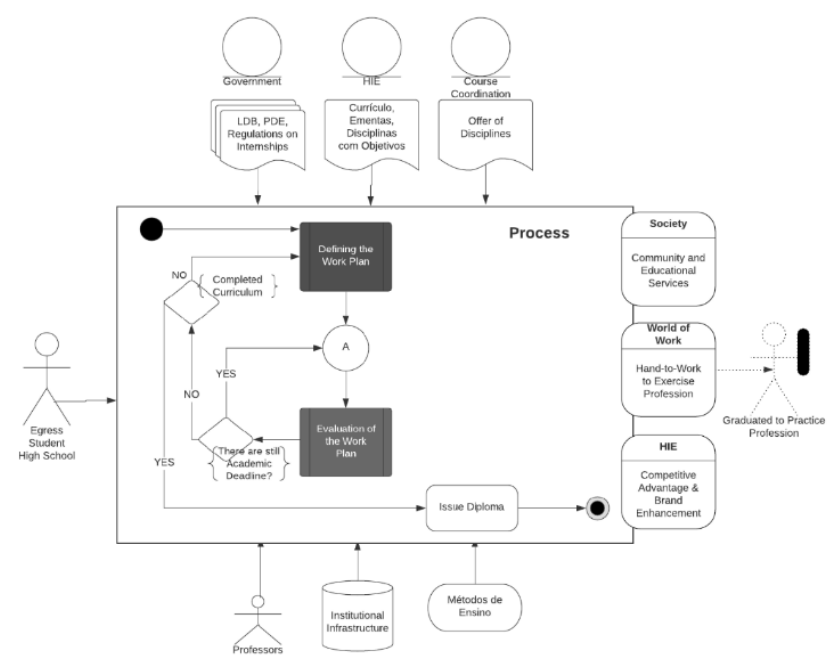

Fig. 1. Academic Process Oriented IES Brands. Source: [10]

Along with the process, guidelines are presented, among which the following stand out: guiding extension projects, scientific and technological initiation for society's demands, and ensuring to disseminate the results obtained in these, as externally, making the non-academic community aware of the functions of the HEIs, as internally, generating a positive internal culture [16], which, in turn, positions the student as co-creator of the image of the HEI [14].

The 'Definition of the Work Plan' occurs at each stage of training, such as academic periods, in periodic meetings of 'individual teaching advice' and consists of the subjects to be fulfilled in the current academic period, scientific initiation project and technology, extension project, internships and monitoring; under teacher guidance. Reference [24] defends the need to help students navigate the academic environment through counseling. Corroborating the idea, [13] concludes that the absence of accommodation practices in the academic process causes students to abandon, and suggests as a solution what he calls orientation and support sessions. Student dropout has a negative impact on the reputational capital of HEIs and should be minimized.

In the 'Work Plan Evaluation', each element of composition is evaluated according to the practices adopted in the HEI, with the addition of the assessment of selfefficacy - set of perceptions that the student has about its value and its potential, which, according to [13], when not positive, they may have an impact on the overdimensioning of the degree of difficulty of academic activities on the part of the students, making them believe that the challenges of the academy are insurmountable, due to the incredulity in their own capacity to overcome; which, in turn, damages the reputation of IES by generating retentions and compromising the image of the institutional brand in the view of these students.

In the execution of the task of 'Evaluation of the Work Plan' of the academic process under study there is also the dissemination of the impacts of extension, scientific or technological initiation, monitoring and internship projects. Thus, both the university community and society in general can have access to what is done in the HEI and its results; which motivate students with a positive university culture and interferes with the institution's reputational capital by bringing it closer to society. Reference [16] state that the students' perceptions regarding the university's reputation interfere and suffer interference from their commitment to it.

Therefore, the 'individual teaching advice', the analysis of 'self-efficacy' and the 'disclosure' of projects and their results in this work are highlighted as essential objects of certification in an academic process oriented to the reputational capital of IES brands. Figure 2.

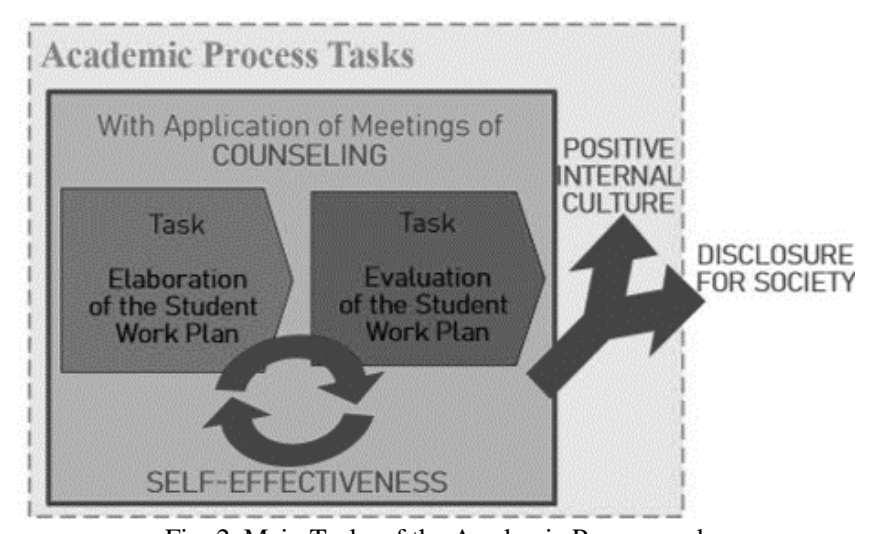

Fig. 2. Main Tasks of the Academic Process and

Certification Objects Oriented to the Reputational Capital of Brands.

The 'Elaboration and Evaluation of the Work Plan' students are the main tasks of the academic process under analysis, carried out through the application of counseling meetings. According to [12], can be called mentoring, and its application has been growing around the world, not necessarily in academia. According to [24], it can be called academic support and corresponds to a service whose objective is to provide information about activities, the importance of commitment to training and standards of coexistence; with a view to contributing to student success.

Reference [19] expand the functions of counseling for the social field, suggesting the incorporation of multicultural skills by the counselors, to, for example, guide undocumented students, such as citizens living in countries other than their homeland, without a visa, and without passing through the formal school.

Self-efficacy is appreciated in the assessment task and has an impact on the definition of the current Work Plan, as well as in the following ones. According to [3] it corresponds to the beliefs that an individual has in his ability to achieve a certain achievement through organization, innovation and execution of a sequence of actions.

Students with impaired self-efficacy have poor performance, do not integrate the institution and are more prone to anxiety and depression, say [18] in research aimed at psychological support for students. The authors conclude that counseling enhances students' academic performance 
and improves the reputation of the HEI.

The dissemination of projects to society and the internal community contributes to develop a positive internal culture and to bring society closer to HEI, generating a positive impact on the image of universities' brands. The certifications in this area, according to [17], are necessary in response to the increase in employers' expectations regarding digital and social skills imposed by technological innovations.

The objective of this is to identify how to carry out the certification of counseling, self-efficacy and the dissemination of the academic process oriented to the reputational capital of brands of Brazilian HEIs.

\section{Methodology}

To identify the articles considered sources of this research, there was an initial selection of articles divided into 3 stages. One focused on 'self-efficacy', the second aimed at 'individual education counseling' and the last one on 'advertising'. All investigations also included 'certification', with the application of the logical operator 'and'.

In the 1st stage, for investigation on 'self-efficacy', a systematic review was carried out on November 1, 2020, using the search string "self-efficacy' AND certification" in the CAPES Portal search engine, linked to the MEC, initially obtaining 4,144 records. Then, a filter was applied for the exclusive selection of articles reviewed by peers, obtaining 3,893. Afterwards, the topic "higher education" was selected, with a reduction in the number of articles to 559. With the definition of the temporal scope from 2015 to 2020 and English as a language, 274 articles remained. Then the abstracts of these were read, reaching a total of 9 articles. O principal critério de inclusão foi a disponibilidade de texto completo, bem como a referência à autoeficácia e à certificação. Figure 3.

\section{Selection of Articles on Self-Efficiency and Certification}

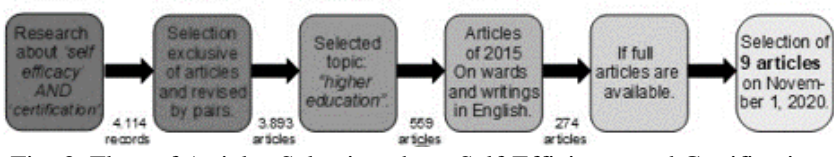

Fig. 3. Flow of Articles Selection about Self-Efficiency and Certification.

On November 4, 2020, the 2nd stage of the methodological flow was carried out with the selection of articles to support the investigation on 'individual education counseling'. Quasi-systematic review was also applied, with the search on the CAPES Portal for the string "individual teaching counseling" AND "certification", with the return of 4,798 works. Afterwards, a filter was applied for the exclusive selection of articles reviewed by peers, obtaining 3,988. Having selected the topic "higher education", the number of articles was reduced to 517. From the delimitation of the time scope from 2015 to 2020 and English as a language, 145 articles remained. Then the abstracts of these were read and 16 articles were obtained. The availability of full text and reference to 'individual education advice' and 'certification' was the main inclusion criteria. Figure 4.
Selection of Articles on Individual Teaching Couseling and Certifications

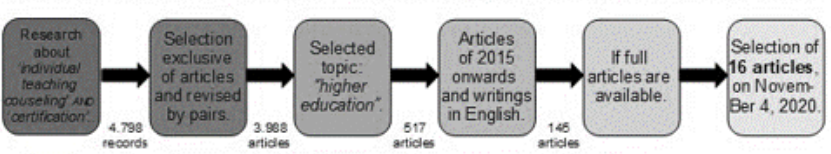

Fig. 4. Flow of Articles Selection about Individual Teaching Counseling and Certification.

Articles about 'disclosure' were selected on November 9, 2020, corresponding to the 3rd stage of the methodological flow. Quasi-systematic review, with the search on the CAPES Portal of the string "advertising" AND "certification" was applied with the return of 16,278 works. With the application of a filter for exclusive selection of peerreviewed articles, 8,682 were obtained. From the selection of the "higher education" topic, the number of articles was reduced to 1,145 . With the delimitation of the time frame from 2015 to 2020 and English as a language, 122 articles remained. Then the abstracts of these were read and 14 articles were obtained. The availability of full text, the reference to 'disclosure' and 'certification' were the main inclusion criteria; and the main exclusion criterion was dealing with marketing education. Figure 5.

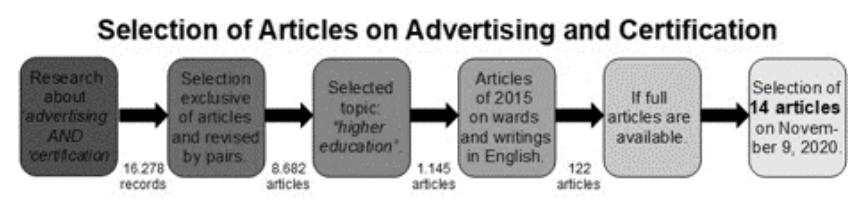

Fig. 5. Flow of Articles about Advertising and Certification.

To compose the complete methodological flow, the selections made in 3 stages were compiled - Figure 6.

After selecting the articles from the analysis of the abstracts, a complete reading of the works was carried out, with 4 articles on 'self-efficacy' being selected, 4 dealing with 'individual teaching advice' and 2 about 'disclosure'; and 4 articles selected from the analysis of the relevance of the references were added, 3 on 'self-efficacy' and 1 on 'individual teaching advice'.

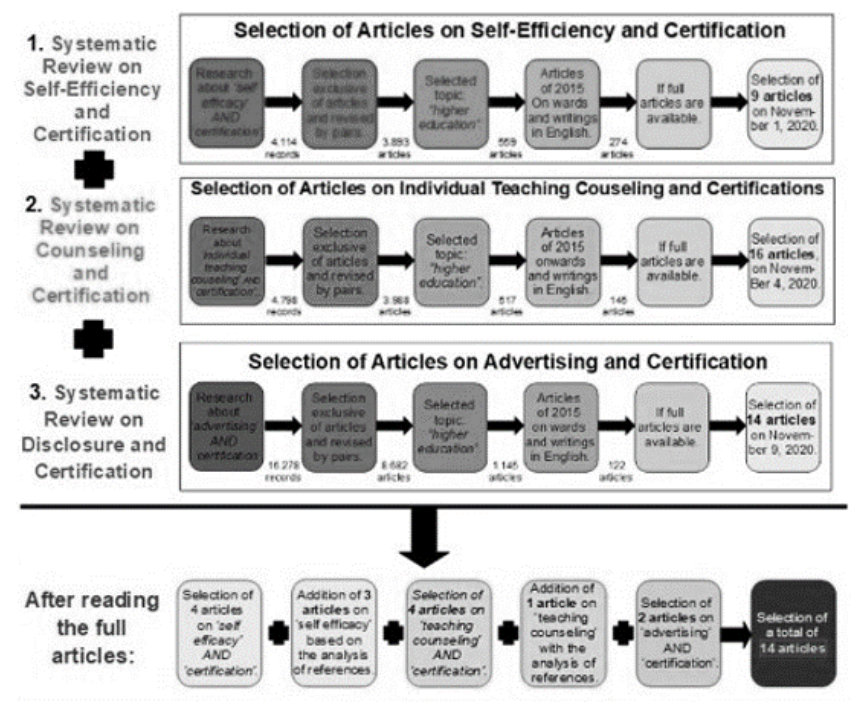

Fig. 6. Methodological Flow.

\section{RESULTS}

Two forms of certifications predominated in conformity assessment in the research corpus: (1) training monitored by assessment and (2) practical tests or challenges. The 
conformity assessment corresponds to the verification of compliance with the requirements previously defined as necessary to parameterize the accreditation. Table I.

The Frame 1 refers to a total of 11 articles despite the selection of 14 papers that were cited before. This is because [7] serve as a theoretical foundation for the work on selfefficacy and music teaching, [4] complements the concepts of self-efficacy and [1] is a theoretical basis that deals with hidden curriculum explored in research by [8].

In addition to the aforementioned forms of certifications, [8] points out the portfolio, applied to document the learning that took place outside the academy, and when 'individual education counseling' is the object of certification.

TABLE I: CERTIFICATIONS WAYS APPLIED

\begin{tabular}{|c|c|c|c|}
\hline $\begin{array}{c}\text { Certifications } \\
\text { Ways }\end{array}$ & References & $\begin{array}{c}\text { Certification } \\
\text { Objects }\end{array}$ & Research Context \\
\hline \multirow{6}{*}{$\begin{array}{l}\text { training in } \\
\text { conjunction } \\
\text { or monitored } \\
\text { by evaluation }\end{array}$} & [20] & \multirow[t]{2}{*}{ self-efficacy } & $\begin{array}{l}\text { Prepares African- } \\
\text { American students, } \\
\text { reinforcing their self- } \\
\text { efficacy, for the } \\
\text { certification required } \\
\text { in a teacher training } \\
\text { plan. }\end{array}$ \\
\hline & [23] & & $\begin{array}{l}\text { Compares the self- } \\
\text { efficacy of teachers of } \\
\text { online courses with } \\
\text { those of classroom } \\
\text { way. }\end{array}$ \\
\hline & {$[12]$} & \multirow{2}{*}{$\begin{array}{l}\text { individual } \\
\text { teaching } \\
\text { counseling }\end{array}$} & $\begin{array}{l}\text { Researches the } \\
\text { formation of } \\
\text { counselors as a } \\
\text { profession. }\end{array}$ \\
\hline & [24] & & $\begin{array}{l}\text { For the analysis of } \\
\text { system performance } \\
\text { for distance learners. }\end{array}$ \\
\hline & [17] & \multirow[t]{2}{*}{ disclosure } & $\begin{array}{l}\text { Researches the benefit } \\
\text { of online training on } \\
\text { dissemination with the } \\
\text { application of } \\
\text { alteration the world of } \\
\text { work. }\end{array}$ \\
\hline & [22] & & $\begin{array}{l}\text { It investigates the } \\
\text { incorporation of } \\
\text { certifications in } \\
\text { training plan in } \\
\text { marketing. }\end{array}$ \\
\hline \multirow{5}{*}{$\begin{array}{l}\text { practice tests } \\
\text { or challenges }\end{array}$} & [25] & \multirow{3}{*}{ self-efficacy } & $\begin{array}{l}\text { Compares group of } \\
\text { music teachers with } \\
\text { traditional training } \\
\text { with group' training } \\
\text { carried out by } \\
\text { certifications. }\end{array}$ \\
\hline & [3] & & $\begin{array}{l}\text { It proposes a } \\
\text { definition for self- } \\
\text { efficacy, as well as a } \\
\text { strategy for its } \\
\text { evaluation. }\end{array}$ \\
\hline & [21] & & $\begin{array}{l}\text { Examines the } \\
\text { perception of self- } \\
\text { efficacy in instruction } \\
\text { of the working with } \\
\text { disabled. }\end{array}$ \\
\hline & [8] & \multirow[t]{2}{*}{$\begin{array}{l}\text { individual } \\
\text { teaching } \\
\text { counseling }\end{array}$} & $\begin{array}{l}\text { It aims to better } \\
\text { understand the } \\
\text { informal learning } \\
\text { process - of the hidden } \\
\text { curriculum, in } \\
\text { counseling. }\end{array}$ \\
\hline & {$[6]$} & & $\begin{array}{l}\text { For training in social } \\
\text { work, it proposes the } \\
\text { participation of interns } \\
\text { in counseling teams. }\end{array}$ \\
\hline
\end{tabular}

The certifications of 'individual teaching counseling', 'student self-efficacy' and 'dissemination' of academic projects and their products contribute to the expansion of the reputational capital of HEI brands, corroborating with [11] that when dealing with training in Neuropsychology, concludes that the certification expands the perception of society, the credits of the area, and professional progress; and with [5], who states that professional certification encourages the development of skills beyond techniques, such as those referring to communication and civility.

In Table II shows the skills stimulated by the certifications related to the respective objects considered in this one.

\begin{tabular}{|c|c|c|}
\hline $\begin{array}{c}\text { Certification } \\
\text { Objects }\end{array}$ & Skills Developed & References \\
\hline \multirow{9}{*}{ self-efficacy } & $\begin{array}{l}\text { minimizing the effects of } \\
\text { previous negative perceptions }\end{array}$ & {$[20],[4]$} \\
\hline & $\begin{array}{l}\text { understanding that skills are } \\
\text { dynamic }\end{array}$ & {$[20]$} \\
\hline & $\begin{array}{l}\text { increasing confidence in } \\
\text { proposing new solutions, } \\
\text { innovating }\end{array}$ & {$[25]$} \\
\hline & development of social skills & \multirow[b]{2}{*}[7]{} \\
\hline & $\begin{array}{l}\text { self-assessment of the } \\
\text { possibility of obtaining positive } \\
\text { results }\end{array}$ & \\
\hline & optimization of coping skills & \multirow{3}{*}[4]{} \\
\hline & stress management & \\
\hline & $\begin{array}{l}\text { bracing of commitment to } \\
\text { career }\end{array}$ & \\
\hline & promoting of learning & [21] \\
\hline \multirow{9}{*}{$\begin{array}{l}\text { individual } \\
\text { teaching } \\
\text { counseling }\end{array}$} & development of self-efficacy & [12] \\
\hline & $\begin{array}{l}\text { participation in the continuous } \\
\text { learning community }\end{array}$ & {$[12],[24]$} \\
\hline & $\begin{array}{l}\text { strengthening of coping } \\
\text { strategies }\end{array}$ & {$[12]$} \\
\hline & $\begin{array}{l}\text { improvement of live together } \\
\text { standards }\end{array}$ & \multirow{2}{*}[12]{,$[8]$} \\
\hline & $\begin{array}{l}\text { improving of career } \\
\text { commitment }\end{array}$ & \\
\hline & $\begin{array}{l}\text { navigation in the academic } \\
\text { scope }\end{array}$ & \multirow{2}{*}[24]{} \\
\hline & $\begin{array}{l}\text { participation and engagement in } \\
\text { academic activities }\end{array}$ & \\
\hline & $\begin{array}{l}\text { improviment of understanding } \\
\text { of the informal learning process }\end{array}$ & {$[8],[24]$} \\
\hline & $\begin{array}{l}\text { definition and evaluation of } \\
\text { goals, objectives and schedule }\end{array}$ & {$[6]$} \\
\hline \multirow{5}{*}{ disclosure } & $\begin{array}{l}\text { consonance between student } \\
\text { training, scientific advances } \\
\text { and preparation for the industry }\end{array}$ & {$[17],[22]$} \\
\hline & $\begin{array}{l}\text { expanding of students' } \\
\text { perception of the effectiveness } \\
\text { of certifications }\end{array}$ & [17] \\
\hline & $\begin{array}{l}\text { time management for fulfilling } \\
\text { self-directed online activities }\end{array}$ & \multirow{3}{*}[22]{} \\
\hline & development of autonomy & \\
\hline & $\begin{array}{l}\text { understanding of the } \\
\text { relationship between theory and } \\
\text { real situations }\end{array}$ & \\
\hline
\end{tabular}

Among the skills presented, 7 that are pointed out by more than one author can be highlighted, including in works that have focus on different objects of certification: minimizing the effects of previous negative perceptions, reaction to failure [20], [4], development of social skills [7], [12], [8], optimization of coping skills [4], [12], strengthening of commitment to career [4], [12], [8], participation in the continuous learning community [12], [24], improviment of understanding of the informal learning process [8], [24] and consonance between student training, scientific advances and preparation for the industry [17], [22]. 


\section{Discussion}

Two main forms of certifications are prevalent: the practical tests also called challenges and the training followed or monitored by evaluation. The certifications, in turn, have the effect of developing student skills, such as strengthening commitment to the career, which has an impact on the image of the HEI brand, which is reflected in society. Seven skills are highlighted from the occurrences of these in the research corpus.

\section{A. Practice Tests or Challenges}

The conclusion of the research by [25] is that the path of training music teachers through 22-week or 12-week online certifications can be a viable entry point for the profession. They state, based on the application of tests as proposed by [7], that self-efficacy, analyzed in relation to the certification route: by graduation versus by online certifications, makes it possible to identify teachers who innovate in the way of teaching, who show confidence to work with parents and the community and to promote music in the educational environment.

The criteria for assessing self-efficacy, according to [7], are past performances results, previous performances experiences of others and verbal persuasion and emotional aspects linked to past experiences.

The self-efficacy test proposed by [3] consists of presenting tasks that vary in difficulty, complexity, stress or another dimension depending on the domain to be explored. Students designate the tasks they think they can do and their degree of certainty. The analysis refers to the degree of congruence between the students' perceptions and the actions in the fulfillment of the tasks.

In the research by [21] the self-efficacy of recently graduated teachers is compared with that of experienced teachers, dedicated to working with students with special needs, using the test proposed by [3] with the conclusion that there is a relationship between teacher self-efficacy and the promotion of student learning.

In assessing and recognizing non-formal learning - in workplaces, internships and self-studies [8], applying advice from experienced consultants, evaluates the experience of novice consultants and establishes challenges in understanding how to support their informal learning process.

Reference [6] understand that academic counseling is an essential responsibility of HEIs and should be carried out by a multidisciplinary team involving social service professionals, whose training they research, proposing that their internship be in counseling teams.

In this way, it is observed that practical tests are applied in certifications of 'self-efficacy' and 'counseling', in different research contexts, with different objectives, of professional teacher training routes, in the work with students with special needs, on learning informal and social service internship monitoring.

\section{B. Practice Tests or Challenges}

The conclusion of the research by [25] is that the path of training music teachers through 22-week or 12-week online certifications can be a viable entry point for the profession. They state, based on the application of tests as proposed by
[7], that self-efficacy, analyzed in relation to the certification route: by graduation versus by online certifications, makes it possible to identify teachers who innovate in the way of teaching, who show confidence to work with parents and the community and to promote music in the educational environment.

The criteria for assessing self-efficacy, according to [7], are past performances results, previous performances experiences of others and verbal persuasion and emotional aspects linked to past experiences.

The self-efficacy test proposed by [3] consists of presenting tasks that vary in difficulty, complexity, stress or another dimension depending on the domain to be explored. Students designate the tasks they think they can do and their degree of certainty. The analysis refers to the degree of congruence between the students' perceptions and the actions in the fulfillment of the tasks.

In the research by [21] the self-efficacy of recently graduated teachers is compared with that of experienced teachers, dedicated to working with students with special needs, using the test proposed by [3] with the conclusion that there is a relationship between teacher self-efficacy and the promotion of student learning.

In assessing and recognizing non-formal learning - in workplaces, internships and self-studies [8], applying advice from experienced consultants, evaluates the experience of novice consultants and establishes challenges in understanding how to support their informal learning process.

Reference [6] understand that academic counseling is an essential responsibility of HEIs and should be carried out by a multidisciplinary team involving social service professionals, whose training they research, proposing that their internship be in counseling teams.

In this way, it is observed that practical tests are applied in certifications of 'self-efficacy' and 'counseling', in different research contexts, with different objectives, of professional teacher training routes, in the work with students with special needs, on learning informal and social service internship monitoring.

\section{Joint or Monitored Training by Evaluation}

Reference 20 in a study aimed at preparing the AfricanAmerican student for certification in a teacher training program, with a view to meeting market policy that requires racial diversity in the workforce, applies certified selfefficacy through training monitored by assessments, as proposed by [3], whose criteria are students 'perceptions of their own exam skills, and considers it important to publicize successes, celebrate and publish students' successful experiences - outreach.

In a research that compared the self-efficacy of teachers of online courses with those of teachers of face-to-face courses, [23] applied self-efficacy assessments also based on the tests proposed by [3] with challenges about, for example, knowledge of content, effective lesson planning, classroom management, time management and assessment application.

Concerning professional development, [12] propose that there be training of counselors as a profession. They turn to certification in counseling, highlighting the need to prepare for multiculture for the professional practice in focus, and 
highlight the need to develop self-efficacy.

Analyzing the online support system, which tracks students from registration to final certification, [24] conclude that they aim to develop navigation skills in the academic environment, encourage participation in academic activities, create academic community and contribute with the construction of student autonomy.

When researching online training certifications on 'outreach', specifically about digital marketing, required by future employers, [17] identify the certifications that are available, what is learned in each certification and the students' perception of their effectiveness. These certifications are aligned to HEIs through inverted classes.

Still on online 'disclosure' certifications, [22] suggest that they be incorporated into university disciplines as they allow exposing students to current resources, offering self-directed and practical learning, and being free or low cost.

Thus, it is possible to observe the application of training and evaluation to certify 'advice', 'self-efficacy' and 'disclosure' in different contexts and objectives.

\section{Skills Developed by Brand-Oriented Certifications}

The 7 skills highlighted, pointed out by more than one author, even in works that focus on different objects of certification, can compose 3 groups according to the benefits they promote to the reputational capital of the HEIs:

1) minimizing the effects of previous negative perceptions, reaction to failure [20], [4] and optimization of coping skills [4], [12] prevent retention and student abandonment, which generates satisfaction and confidence in students and contribute to the quality of services that graduates provide to society;

2) development of social skills [7], [12], [8] and improved understanding of the informal learning process [8], [24] meet labor market requirements since both social skills and informal learning, for example engagement and respect for rules, are required in the exercise of any profession and favors the image of the institutional brand;

3) strengthening career commitment [4], [12], [8], participation in a continuous learning community [12], [24] and consonance between student training, scientific advances and preparation for the industry [17], [22] promote adequate training and updating, adequately meeting the demands of society, which contributes to the expansion of the HEI's reputation.

\section{CONCLUSION}

The certifications of 'individual education counseling', 'self-efficacy' and 'disclosure' - components of the academic process oriented to the reputational capital of Brazilian HEI brands, have been successfully carried out through training followed or monitored by evaluations and through practical tests also called challenges. It is said that there is success because it is observed, according to the conclusions of the scientific investigations considered, that they develop skills that have the impact of expanding the reputational capital of universities.

Analyzing the scopes present in the corpus of this research, it is noted that certifications under analysis are also useful for: supporting professional training programs, guiding worker evaluations, composing functionality of an online education system, encouraging employees to innovate, promoting student learning and serving like parameter for assessment and recognition of informal learning.

The HEIs' reputation is benefited because it is observed that it is possible to minimize academic retentions and dropouts, which promotes satisfaction and confidence in graduates; considers the requirements of the labor market focused on social skills, motivation and respect for rules; strengthens the commitment to the career and stimulates the permanent formation, which results in improvement in the service of the society and reflects positively on the institutional brand.

\section{REFERENCES}

[1] S. Abbot (2014) Hidden Curriculum. 2014, August 26, edited by S Abbott. The glossary of education reform. [Online]. Available: http://edglossary.org/hidden-curriculum.

[2] ABPMP (2013) BPM CBOK Versão 3.0 - Guia para o Gerenciamento de Processos de Negócio Corpo Comum de Conhecimento, [Online] Association of Bussiness Process Management Professionals, Brasil Available: <abpmp-br.org>

[3] A. Bandura (1982). Self-efficacy mechanism in human agency. American Psychologist. [Online]. 37, pp. 122-47. Available: d1wqtxts1xzle7.cloudfront.net/60667388/SelfEfficacy_Bandura198220190922-26039

[4] M. J. Bergee (2002). Direct and mediated experiences: Effects on classroom management selfefficacy. Journal of Music Teacher Education. [Online]. 12:1, pp. 33-37. Available: sagepub.com.

[5] O. Bertrand (2005). Avaliação e certificação de competências e qualificações profissionais. Título Original: Evaluación y certificación de competencias y calificaciones profesionales. [Online]. UNESCO/ IIPE, Brasilia.

[6] M. L. Bessaha, C. Solis, C. Franks, H. Yoon, D. Dualeh, H. MonroyCaceres, G. Cuesta and E. Rodriguez (2018) Social Work in Higher Education: Internships in Opportunity Programs, Journal of Teaching in Social Work. [Online]. 38:4, pp. 417-430, Available: doi:10.1080/08841233.2018. 1500412.

[7] M. Biasutti and Concina (2017) The effective music teacher: The influence of personal, social, and cognitive dimensions on music teacher self-efficacy. Musicae Scientiae Advance. [Online]. Available: doi:10.1177/1029864916685929.

[8] N. Burkšaitienè, (2015) Assessment and recognition of non-formal and informal learning: a Lithuanian case of novice consultants' experience, International Journal of Lifelong Education. [Online]. 34:6, pp. 643662. Available: doi: 10.1080/02601370.2015.1091392.

[9] R. T. Burlton (2001) Business Process Management: Profiting From Process. [Online]. SAMS, Indianapolis - USA. Available: books.google.com.br/.

[10] K. K. Cox and R. De-Bortoli, Robelius. (2020) Academic Process Oriented to the Reputational Capital of Brazilian HEI Brands. International Journal for Innovation Education and Research. [Online]. 8:12, pp. 238-261. Available: ijier.net/ijier/article/ view/2836

[11] R. L. Denney (2010). Authentic Professional Competence in Clinical Neuropsychology, Archives of Clinical Neuropsychology. [Online]. 25:5, pp. 457-467. Available: doirg.ez20.periodicos.capes.gov.br/10.1093/arclin/acq046

[12] D. L. Duenyas, S. Akcil and C. Osborn (2020) Professional Adjustment Experiences of International Counseling GraduatesInternational, Journal for the Advancement of Counselling. [Online]. 42, pp. 21-36. Available: doi.org/10.1007/s10447-01909386-6>.

[13] Frasineanu, E. S. (2019) The beginning of studies and the prediction of university abandonment, Revue des Sciences Politiques. [Online]. 61, pp. 68-79. Available: cis01.central.ucv.ro/ revistadestiintepolitice/files/ numarul61_2019/7.pdf>.

[14] P. Foroudi, Q. Yu, S. Gupta, M. M. Foroud. (2019) Enhancing university brand image and reputation through customer value cocreation behaviour, Technological Forecasting \& Social Change. [Online]. 138, pp. 218-227. Available: elsevier.com/locate/techfore.

[15] H. Gwo-Haur, C. Beyin and H. Cin-Wei. (2016). Development and Effectiveness Analysis of a Pemonalized Ubiquitous Multi- Ikvice Certification Tutoring System Based on Bloom's Taxonomy of 
Educational Objectives. Educational Technology \& Society. [Online]. 19:1, pp. 223-236. Available: https://eric.ed.gov/?id=EJ1087106.

[16] J. Hemsley-Brown, T. C. Meleware, B. Nguyen and E. Wilson. (2016) Exploring brand identity, meaning, image, and reputation (BIMIR) in higher education: A special section, Journal of Business Research. [Online]. 69, pp. 3019-3022. Available: dx.doi.org/10.1016/j.jbusres. 2016.01.016.

[17] G. Laverie, W. Humphrey, K. T. Manis and K. Freberg. (2020) The Digital Era Has Changed Marketing: A Guide To Using Industry Certifications And Exploration Of Student Perceptions Of Effectiveness, Marketing Education Review. [Online]. 30:1, pp. 5780, Available: doi:10.1080/10528008.2020.1716806.

[18] M. Munyaradzi and D. Addae. (2019) Effectiveness of Student Psychological Support Services at a Technical and Vocational Education and Training College in South Africa Community College, Journal of Research and Practice. [Online]. 43:4, pp. 262-274. Available: doi: 10.1080/ 10668926.2018.1456379.

[19] H. K. Nienhusser and M. M. Espino. (2017) Incorporating Undocumented/DACAmented Status Competency Into Higher Education Institutional Agents' Practice, Journal of Student Affairs Research and Practice. [Online]. 54:1, pp. 1-14. Available: doi: $10.1080 / 19496591.2016 .1194286$.

[20] E. Petchauer. (2016) Shall We Overcome? Self-Efficacy, TeacherLicensure Exams, and African American Preservice Teachers, The New Educator. [Online]. 12:2, pp. 171-190. Available: $<$ doi.org/10.1080/1547688X.2016.1156456.

[21] M. E. Reyes, C. J. Hutchinson and M. Little. (2017) Preparing Educators to Teach Effectively in Inclusive Settings, SRATE Journal. [Online]. 26:1, pp. 21-29 Win 2017. Available: https://files.eric.ed.gov/fulltext/EJ1134393.pdf.

[22] L. Spiller and T. Tuten. (2019) Assessing the Pedagogical Value of Branded Digital Marketing Certification Programs, Journal of Marketing Education. [Online]. 41:2, pp. 77-90. Available: doi: $10.1177 / 0273475318822686$.

[23] K. Stricklin and B. Tingle (2016) Using Online Education to Transition Teaching Assistants to Teacher Certification: Examining the Differences Between Teacher Education Programs, American Journal of Distance Education. [Online]. 30:3, pp. 192-202. Available: doi: 10.1080/08923647. 2016.1192840.

[24] A. Walters-Archie (2018) Academic support for online students in the English-speaking Caribbean at the University of the West Indies Open Campus, Journal of Further and Higher Education. [Online]. 42:6, pp. 868-878. Available: doi: 10.1080/0309877X.2017.1332353.

[25] J. J. West and M. L. Frey-Clark. (2018) Traditional Versus Alternative Pathways to Certification: Assessing Differences in Music Teacher Self-Efficacy, Journal of Music Teacher Education. [Online]. 28:2, pp. 98-111. Available: doi.org/10.1177/1057083718788035.

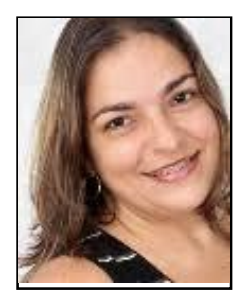

K. K. Cox, Bachelor of Computer Science - UFS

Master in Education - UFS

Professor of the Department of Computing - UFS

Doctoral student of the Graduate

Program in Intellectual Property Science - UFS

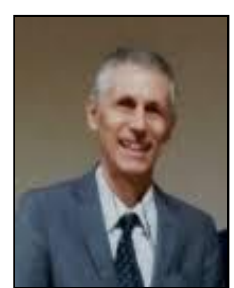

R. De-Bortoli, Degree in Physical Education - UFRGS

Specialist in Football Administration and Marketing - UGF

Doctor of Science in Physical Activity - UNILEON

Post-Doctorate by the University of Costa Rica 